\title{
Symposium: The Informal Economy
}

\section{"An Honest Living": \\ Street Vendors, Municipal Regulation, and the Black Public Sphere}

\section{Regina Austin ${ }^{\dagger}$}

I, like many blacks, believe that an oppressed people should not be too law abiding, especially where economics is concerned. ${ }^{1}$ The economic system that has exploited us is not likely to be effectively exploited by us if we pay too much attention to the law. Moreover, for some poor blacks, breaking the law is not only a way of life; it is the only way to survive. Thus, what is characterized as economic deviance in the eyes of a majority of people may be viewed as economic resistance by a significant number of blacks.

I am not asserting that blacks advocate anarchy, nor do I believe that they romanticize lawbreaking more than anyone else. Rather, I am simply arguing that many blacks rightly understand that the line between the legal and the illegal in the area of economic activity is ephemeral and that the determination of the precise point at which the line is drawn is a matter of political struggle. Accordingly, blacks need to be in the thick of the battle, fighting for their

$\dagger$ Professor of Law, University of Pennsylvania. I want to thank the numerous persons who spoke to me on the subject of black vendors, particularly Wallace Ford, III, former Commissioner of Business Services of New York City; Hakim S. Hasan; Elijah Karriem; Robyn Millman, Esq.; Jade Powell; and Professor Paul Stoller. I also want to thank Keisha Ann Gray for her research assistance and Manthia Diawara for his support.

1. See generally Regina Austin, "The Black Community," Its Lawbreakers, and a Politics of Identification, 65 S. CAL. L. REV. 1769 (1992) (exploring positive and negative aspects of lawbreaking from perspective of various socioeconomic segments of black community). 
interests. That means condoning, abetting, and sometimes even engaging in illegal activity.

Blacks must be especially vigilant with regard to the local regulation of entrepreneurial activity, because the well-being of the black public sphere hinges upon it. When I speak of the black public sphere, I refer to a realm that includes not just politics, but also economics. ${ }^{2}$ Blacks must develop outlets, both audiences and markets, for the products of their labor and creative genius. Black people need jobs. They need institutions and business concerns that black people control. They need the protection of an ethic that discourages exploitation in commercial and personal relationships. All of this requires that blacks come together to defy the system that has almost entirely foreclosed them from the realm of production and commerce.

The call for a reinvigorated, expanded black public sphere is the result of a growing realization among blacks that the problems of those on the bottom of the socioeconomic ladder do not result totally from disparities in income and impediments to consumption that can be solved by allowing workers to recapture more of the surplus produced by their labor. The maldistribution and free mobility of capital and wealth threaten those whose economic security is tied to their status as wage earners. Blacks who have not secured employment in the formal labor market are in the worst possible position. Furthermore, the line between employer and employee is blurring, as is clear from the extent of subcontracting, for example. The only way blacks can maintain even the relative status quo in this economy is to play a more significant role in production and commerce. The success that other groups have found in pursuing activities in the informal economy suggests that blacks must undertake new forms of "civil disobedience" in the name of economic survival.

Street vending amply illustrates my hypothesis. At this late date in modernity or post-modernity, many indigenous blacks continue to use urban sidewalks for commercial purposes. In places like New York City, Washington, D.C., and Philadelphia, most black street vendors work without a license and in violation of applicable vending regulations and sales tax laws. Yet, when asked about their illegal status, the vendors maintain that vending is an "honest living" that they should be allowed to pursue legally. ${ }^{3}$

2. See generally Regina Austin, "A Nation of Thieves": Securing Black People's Right To Shop and To Sell in White America, 1994 UTAH L. REV. 149 (1994).

3. See Carolyn A. Butts, 125th Street Vendors Pledge To Fight Law To Protect Turf, N.Y. AMSTERDAM NEwS, Oct. 27, 1990, at 4 (quoting female vendor who says of her work: "On the street peddling-this is honest. The only difference is we are not paying rent."); Julian Jingles, 125th Street Vendors: A Dilemma with Great Potential Results, N.Y. AMSTERDAM NEwS, July 3, 1993, at 3, 38 (describing unlicensed street vendor who says he will not be deterred from doing what he is doing, which is "making an honest living"); see also Josephine Smart, How To Survive in Illegal Street Hawking in Hong Kong, in TRADERS Versus tHE STATE: ANTHROPOLOGICAL APPROACHES TO UNOFFICIAL ECONOMIES 99, 103 (Gracia Clark ed., 1988) [hereinafter TRADERS VERSUS THE STATE] (illegal hawkers consider themselves "legitimate small businessmen earning an honest living by serving the public"). 
In the past several years, legislators and municipal authorities in a number of cities throughout the country have tackled the problem of street vending, and the general direction of their reform and enforcement efforts has been unfavorable to vendors. ${ }^{4}$ If regulations do not explicitly ban street vending, they hamper it by limiting the number of vending licenses, raising the licensing fees, restricting vending locations, or prescribing modes of operation (including hours of operation, cart design, or table dimensions).

Struggles over the regulation of street vending are nothing new. Cities have a long history of trying to drive vendors from the streets or to restrict their access to pedestrian traffic..$^{5}$ Wherever and whenever street vendors appear, controversies over street vending almost always pit the same groups against each other. On one side are the vendors, their loyal customers, and those who are interested in the welfare of recent immigrants or the marginally employed. On the other side are city authorities concerned about taxes, congestion, sanitation, aesthetics, and property values; fixed-location merchants, who must compete with vendors whose only overhead concern is the weather; producers and distributors, who want to know how their wares wind up on vendors' tables; and middle-class residents who prefer streets

4. See, e.g., Ruben Castaneda, Vendors Raise Howl Over Higher Fee Plan, WASH. POST, Feb. 5, 1993, at D1 (citing D.C. vendors' objections to proposed increase in vending fees from $\$ 130$ to $\$ 1500$ ); Jennifer F. Parker, Street Vendors: New Rules Offer Chance To Sell Wares, ATLANTA J. \& ConST., July 15, 1993, at D1 (predicting impact of new, more stringent vending regulations on existing and prospective vendors, most of whom are black males); James Rainey, Vendors Cheer as Legalization Wins Final OK, L.A. TuMES, Jan. 5, 1994, at 1A (Los Angeles City Council approves establishment of eight vending districts for vendors who secure approval of local residents and businesses); Vanessa Williams, New Rules on Street Vendors Draw Near, PHILA. INQUIRER, Feb. 11, 1993, at B1 (Philadelphia black and Korean vendors concemed that allocation of 300 vending locations according to seniority system will cost them their livelihoods); Tao Wolfe, Vendors Must Get Off the Streets: Rule Puts Public Land Off-limits to Peddlers, Sun SENTINEL, Jan. 3, 1994, at B1 (Fort Lauderdale bars vendors from all public property, including streets).

The trend in favor of greater regulation of street vendors is also reflected in a spate of recent cases upholding local vending laws. See, e.g., Story v. Green, 978 F.2d 60 (2d Cir. 1992) (upholding measure ending exemption of veterans from municipal vending regulations in New York City); Hispanic Taco Vendors v. City of Pasco, 790 F. Supp. 1023 (E.D. Wash. 1991) (rejecting constitutional challenge to local vending provisions imposing annual fee of $\$ 600$, prohibiting use of vacant lots, and requiring that vendors be associated with a permanent business); Operation New Birmingham v. Flynn, 621 So. 2d 1316 (Ala. 1993) (upholding power of city under state law to license vendors with condition that license might be revoked upon complaint of fixed-location merchant). But see Barajas v. City of Anaheim, 19 Cal. Rptr. 2d 764 (1993) (holding that state motor vehicle code preempts city ordinance banning vending from vehicles parked on public streets in residential zones).

In fact, over the past twenty years or so, there have been numerous cases rejecting legal challenges to local vending laws. See, e.g., City of New Orleans v. Dukes, 427 U.S. 297 (1976) (upholding local ordinance barring all vendors from the Vieux Carre except those who had operated continuously for eight years); Service Employees Int'1 Union, Local 82 v. District of Columbia, 608 F. Supp. 1434 (D.D.C. 1985) (upholding constitutionality of restrictions on location, cart design, overnight storage, and merchandise sold); Kleiber v. City of Idaho Falls, 716 P.2d 1273 (Idaho 1986) (rejecting vendor's attack of a law entirely prohibiting vending on public sidewalks); Fetfatzes v. City of Philadelphia, 529 A.2d 1220 (Pa. Commw. Ct. 1987) (upholding city's right to prohibit vending in locations where it was previously permitted); Hixon v. State, 523 S.W.2d 711 (Tex. Crim. App. 1975) (upholding ordinance making it illegal to sell merchandise on street).

5. See Daniel M. Bluestone, "The Pushcart Evil": Peddlers, Merchants, and New York City's Streets, 1890-1940, 18 J. URB. HIST. 68 (1991). 
marked by order and decorum, rather than by the chaos and confusion of Old World bazaars. Naturally, the interests of these contending forces are balanced differently in every instance, the outcome being determined according to the relative political clout of the opposing parties.

While no single best solution emerges to the problems posed by contemporary urban street selling, ${ }^{6} \mathrm{I}$ would argue that in the American economy of today, race makes a difference. Debates over the regulation of street vending should accordingly include some discussion of exactly how race makes a difference. This does not mean that black vendors ought to prevail in every case. The mix is more complicated than that. Whereas in the past the forces opposing black street vendors were almost exclusively white, increasingly the fixed-location merchants are black, brown, or Asian; the producers are black; and the municipal authorities are black too. With blacks on both sides of the equation, class differences within "the black community" assume new prominence. This interplay of race and class influences where the balance between the rights of vendors and those of others ought to be struck. What I am arguing here is that the history of blacks' foreclosure from production and commerce, and the need to invigorate and further develop the black public sphere, warrant that special attention be paid to even the pettiest form of black entrepreneurial activity.

$$
* * * * * * *
$$

One cannot assess the importance of black street vending to the black public sphere without first considering a few basic macroeconomic facts. Official rates of black unemployment are nearly twice those of whites. ${ }^{7}$ Moreover, relative to other groups, blacks are underrepresented among business owners and the self-employed. ${ }^{8}$ Although black households spend an estimated $\$ 216$ billion per year, the total sales of black businesses equal only $10 \%$ of that amount.9 At the same time, shoppers in inner city black communities confront a retail market characterized by poor quality, high prices, and a limited choice of goods offered by a limited number of accessible retail

6. Lawrence O. Houstoun, Jr., Streetwise, PLANNING, May 1993, at 20 (recounting variety of ways in which cities are coping with increasing numbers of street vendors).

7. In 1993, the unemployment rate for whites was $6.0 \%$, while that for blacks was $12.9 \%$. BUREAU OF LABOR STATISTICS, U.S. DEP'T OF LABOR, EMPLOYMENT AND EARNINGS 232 (Jan. 1994) [hereinafter EMPLOYMENT AND EARNINGS].

8. Only $3.1 \%$ of firms in the United States are black-owned and they account for only $1 \%$ of gross receipts. BUREAU OF THE CENSUS, U.S. DEP'T OF COMMERCE, 1987 SURVEY OF MINORITY-OWNED ENTERPRISES 4 (1990). In 1993, blacks constituted 4.8\% (429,000 out of a total of 9 billion) of selfemployed nonagricultural workers. EMPLOYMENT AND EARNINGS, supra note 7, at 230.

9. Marcus Alexis \& Geraldine R. Henderson, The Economic Base of African-American Communities: A Study of Consumption Patterns, in THE STATE OF BLACK AMERICA 1994, at 51, 81 (Billy J. Tidwell ed., 1994). 
outlets. ${ }^{10}$ Blacks also demand certain culture-specific products, like books and apparel, that mainstream suppliers do not or will not supply. ${ }^{11}$

Street vending fills a small part of the void created by the economic marginalization of black Americans as workers, owners, and consumers. Illegal, informal street vending employs people. It supplies blacks with goods they need and want. It contributes to the maintenance of black culture. It challenges nonblack businesses in black enclaves. It helps people gain the capital and know-how to operate businesses in the formal sector. Finally, it is the site of grassroots activity that could lead to new initiatives uniting the political and economic concerns of blacks.

It is impossible to determine the impact of vending on black under- and unemployment. Black street vendors are a disparate lot; they defy profiles. Some folks are vending because they have an entrepreneurial bent and want to work for themselves. Many show the dedication and commitment that it would take to hold down a regular job. Some vendors, however, maintain that if they were not on the streets selling they would be on welfare or homeless. ${ }^{12}$ Moreover, black vendors include persons from marginalized groups within the black community, such as religious adherents, artists, and women. ${ }^{13}$ Finally, native-born vendors are joined on the streets by recent arrivals from Africa and the Caribbean, whose limited English proficiency and questionable immigration status limit their options for earning a living.

Street vending efficiently delivers certain kinds of wares to the inhabitants of black enclaves. A walk down 125th Street in Harlem on a cold overcast weekday reveals tables loaded with knit hats, gloves, and scarves (mostly in the standard colors, but some with color combinations that seem distinctly African); sweatshirts (bearing Polo and Timberland logos or the insignias of black universities); flannel vests; video tapes (on tables with video players going); audio tapes (some wrapped in thick cellophane and bearing the names of lesser-known gospel, rap, and reggae artists); jewelry; cosmetics and hair care products; books (basic black texts and spiritual offerings); incense,

10. See Mark Alpert, The Ghetto's Hidden Wealth, FoRTUNE, July 29, 1991, at 167 (reporting that inner city markets are underserved as to both variety and quality of stores because of misconceptions about income levels of community); Francine Schwadel, Urban Consumers Pay More and Get Less, and Gap May Widen, WALL ST. J., July 2, 1992, at Al (documenting extent to which inner city residents pay higher prices for goods ranging from furniture and appliances to McDonald's Big Macs). But see Susan Diesenhouse, As Suburbs Slow, Supermarkets Return to Cities, N.Y. TIMES, June 27, 1993, § 3, at 5 (explaining how supermarket chains are returning to urban markets in pursuit of profits).

11. See infra text accompanying note 16 .

12. Karen Carrillo, CB1O Said To Seek To Have Harlem Street Vendors Thrown Out of 125 St., N.Y. AMSTERDAM NEwS, Dec. 14, 1991, at 10, 34 (summarizing comments of vendors amassing to attend public hearing).

13. The lot of the black female vendor is tougher than that of the black male vendor, because the female has to deal with the varieties of male supremacy she encounters from the black and white males with whom she deals. See Roberta M. Spalter-Roth, The Sexual Political Economy of Street Vending in Washington, D.C., in TRADERS VERSUS THE STATE, supra note 3, at 165, 172-73; Roberta M. Spalter-Roth, Vending on the Streets: City Policy, Gentrification, and Public Patriarchy, in WOMEN AND THE POLITICS OF EMPOWERMENT 272 (Ann Bookman \& Sandra Morgen eds., 1988). 
essences, herbs, and roots; African apparel; bogus designer watches; leather goods; and sunglasses. Most of this merchandise is manufactured or massproduced, not unique or handmade. The manufacture and distribution of these products may occur in either the formal or informal sector. When considered in the larger context, street vending cannot be dismissed as petty hustling; rather, it is the most basic form of retailing. ${ }^{14}$ Street vending serves as the last link in the chain of distribution for products that are best produced in limited quantities or distributed through small-scale retail operations that survive on slender profit margins.

Street vending is an economically viable way of selling such goods (and of earning a living) for several reasons. ${ }^{15}$ As self-employed individuals, vendors are free to exploit themselves as much as they want. They can potentially increase their sales by maintaining long hours or by working in miserable conditions. Because they are both close to their customers and maintain relatively small stocks of goods, vendors can gauge shifts in customer demand and adjust their inventories quickly. Of course, vendors can charge less than fixed-location merchants because the vendors do not pay rent, utilities, wages, taxes, or other overhead costs, nor do they extend warranties. This makes the vendors' merchandise more affordable to poorer customers.

Black vendors also succeed by catering to the specialized demands of black consumers. Black vendors are purveyors of black culture. Shoppers purchase from vendors "ethnic products" that the shoppers may be unable to find anywhere else. The vendors' wares reflect the renewed interest among indigenous blacks in things African-particularly fabrics, hats, jewelry, and clothes. Although large retailers like J.C. Penney are selling African-inspired merchandise ${ }^{16}$ they cannot match the claims of authenticity attached to goods sold by African street vendors. Books, written by and about black people, are another vending staple. I have seen book stands with wider and more comprehensive inventories than those of established black book stores, and I have talked to street vendors who know all about the books they sell.

Beyond the benefits of the merchandise itself, street vending creates performance space for intellectual debates, spiritual communion, and the pursuit of the pleasures of shopping. Street vendors lend the flavor of an African marketplace to otherwise drab stretches of empty stores and barred façades. The customers move from one vendor to the next "with more control

14. See generally Alejandro Portes \& Saskia Sassen-Koob, Making It Underground: Comparative Material on the Informal Sector in Western Market Economies, 93 AM. J. Soc. 30, 37-40 (1987).

15. See SASKIA SASSEN, The Global CrTy: New YoRK, London, ToKYo 288-94 (1991) (describing forces that drive informal sector in New York City, including inadequate provision of goods and services by formal sector).

16. See Bonnie N. Stanley, Mainstream Catalogs Go "Authentic," RiCHMOND Times-DisPATCH, Sept. 28, 1993, at D4 (discussing catalogs issued by J.C. Penney and Spiegel featuring African-inspired merchandise). 
and less formality than if they were in a store."17 Though customers esteem brand-names and established retailers with fine reputations, they also appreciate friendly service and a fair price. In discussing the merchandise, haggling over prices, and persuading or being persuaded to buy, the vendor and the customer have greater personal interaction than typically occurs in indoor-store sales transactions. There is a certain skill involved in negotiating transactions on the street that animates buyers and sellers alike. As one vendor said of vending, "'Nothing beats getting out here talking to people. Everybody can't do it .... It's a lost trade, a lost art."

Not everyone has a high regard for black street vendors. Some hold vendors in contempt. ${ }^{19}$ In their view, vendors either attract thieves, con artists, drug dealers, pickpockets, or three-card monte players, or they are in cahoots with them (as fences and the holders of money and merchandise). Vendors generally cannot be trusted; when a vendor tells a customer that a piece of merchandise was made in Africa, it often turns out to have been made someplace else. Counterfeit goods abound, as does poor quality. ${ }^{20}$ So many black-authored books are allegedly being pilfered from the shelves of mainstream bookstores for resale on the streets that the books are being removed from browsing areas. ${ }^{21}$ Finally, vendors frequently harass shoppers who patronize stores owned by nonblacks. At the same time, there are blacks who believe that foreign-born vendors are really fronts for white and Asian wholesalers and producers who have facilitated the vendors' immigration into the United States. ${ }^{22}$ Whether or not these assertions are true, vending regulations should be sensitive to the concerns voiced by black consumers and the residents of black communities in which vendors ply their trade.

Another group of relevant economic actors, the fixed-location merchants, is likely to be of two minds about the vendors. ${ }^{23}$ On one hand, the vendors

17. Jingles, supra note 3 , at 3 .

18. Butts, supra note 3 , at 4,40 .

19. Who's 'Beating' Who? Are Black Street Vendors Getting a Fair Deal?, MiCH. CHRON., May 9 , 1990, at 6A.

20. Ben Chant, Street Smarts, NEW YoRK, May 1, 1989, at 68.

21. Clarence Page, Books That Are Too Hot To Handle, CHI. TRIB., Oct. 11, 1992, § 4, at 3 (describing how the shoplifting of black books affects buyers who patronize mainstream bookstores); David Streitfield, Book Report, WASH. POST, Aug. 23, 1992, at X15 (describing how chain stores are responding to disappearance of black books that have become "runaway bestsellers").

22. Julian Jingles, Vendors: Is There an Organized Group Behind Counterfeiters?, N.Y. AMSTERDAM NEws, July 10,1993, at 3 (head of Harlem Urban Development Council wonders whether people are being imported from other countries to sell counterfeit goods on 125th Street).

Rather than being the product of a conspiracy or syndicate, it seems more likely that the concentration of African immigrants in certain kinds of vending is a manifestation of "an efficient ethnic network" that absorbs new immigrants from the time they catch a taxi at the airport and introduces them to vending opportunities opened up by those who preceded them. See Deborah Sontag, Unlicensed Peddlers, Unfettered Dreams, N.Y. TIMES, June 14, 1993, at A1, B2.

23. See, e.g., George E. Jordan, 125th Street Battle: It's a Turf War, Shopkeepers Against the Street Vendors, NEwSDAY, Dec. 21, 1992, at 6 (claiming that some merchants fear reprisals for taking action against vendors, while others believe presence of vendors attracts customers); Shawn G. Kennedy, New Momentum Builds on 125th Street, N.Y. TIMES, Nov. 8, 1992, § 10, at 1, 6 (reporting that vendors hurt 
may attract customers to an area and provide a measure of safety for merchants and customers alike by maintaining a presence on the street. On the other hand, the vendors are competitors who cut into the merchants' profits. The vendors have an advantage over the merchants, who are saddled with fixed costs that the vendors avoid by doing business on the sidewalk. Beyond that, the vendors also create congestion and cause distractions that render nearby shops and stores nearly invisible to passing pedestrians. Some consumers are reluctant to run a gauntlet of vendors to get where they want to go. The vendors also generate litter, for which merchants may be fined for failure to clean up. Merchants fear that vendors will retaliate physically or verbally, or organize protests if the merchants complain to the authorities about the vendors' behavior or mere presence.

Furthermore, street vending may have a negative impact on the overall reputation and ambience of a commercial area, which in turn will reduce the desirability of the location for merchants and the fair market value of the properties. Vending conflicts, at base, are disputes about land use and property values. ${ }^{24}$ Black enclaves that are struggling to attract or hold on to established chain stores and their upscale customers, or to increase or stabilize property values, may not, in the long run, be well-served by vendors. ${ }^{25}$

The black vendors' replies to the criticisms of fixed-location merchants have typically been race-based. Vendors complain that, as between black street vendors and nonblack merchants, the street vendors ought to prevail, because blacks should control the businesses in their own communities. As Morris Powell, president of the 125th Street Vendors Association, put it:

In the Jewish community, the business life is controlled by the Jews; the Italians handle everything in the Italian community. The Chinese control Chinatown; Arabs take care of business among Arabs; Koreans follow the same pattern. But in a Black community, all species of different races run and control our business life among our Black consumers, while the Black business element among us is out on the sidewalk ... ${ }^{26}$

Merchants who attempt to restrict black vendors' operations are labeled by the vendors as outsiders, who should have no standing to prevent blacks from

merchants' business, but that black merchants may be reluctant to have black vendors removed); Ronald Sullivan, Crackdown on Vendors in the Streets, N.Y. TIMES, Apr. 13, 1993, at B1 (relating that merchants blame vendors for cutting into their profits).

24. See Gracia Clark, Introduction to TRADERS Versus tHE STATE, supra note 3, at 1, 11 (vendor licensing initiatives are really product of disguised land use disputes); Johanna Lessinger, Trader $v$. Developer: The Market Relocation Issue in an Indian City, in TRADERS Versus THE STATE, supra, at 139, 141 (conflicts over markets located on increasingly valuable land are "deep-seated struggles over the control and use of urban space").

25. See Jingles, supra note 22, at 48 (president of Harlem Urban Development Council worries that vendors may deter middle-class residents from patronizing business establishments on 125 th Street).

26. Jingles, supra note 3 , at 38 . 
making money in their own communities. ${ }^{27}$ Furthermore, the merchants are criticized because, compared with what the merchants make on sales to blacks, the black street vendors are only getting the crumbs. ${ }^{28}$

These are old refrains. ${ }^{29}$ Blacks' complaints about the nonblack ownership of local businesses are the product, in part, of racial pride or racist jealousy. But the grievances also relate to blacks' concern about their ability to find employment and to amass capital from an array of community-based businesses and financial institutions that are committed to serving blacks. Income gains will not translate into increased wealth if merchants take the dollars spent by blacks and invest them outside the black community.

Race-based turf arguments have less punch in communities where blacks are substantially represented among fixed-location merchants. Of course, the extent to which the arguments lose efficacy depends on the size of the black merchant contingent, a matter of debate in some jurisdictions. In a contest between black fixed-location merchants and black street vendors, the fixedlocation merchants may be financially better off than their vending sisters and brothers, but the merchants typically have more at risk than the vendors, and the community may have a greater stake in the success of the merchants as well. It does not seem sensible or fair to penalize merchants for being in a position to which street vendors aspire.

Indeed, one justification for black street vending is that it is a step on the road to more successful formal black businesses. Vending operations are said to be embryonic businesses that allow blacks to acquire the skills and resources that it takes to operate at a fixed location. This notion may be a bit optimistic, however. The costs of setting up business at a permanent site are prohibitively high for most black street vendors, and the chances of their succeeding are rather poor. ${ }^{30}$ It is not surprising, then, that few vendors are willing to take

27. See, e.g., Lynn Cowan, 125th Street Vendors Call Laws on Street Sales Unfair, N.Y. AMSTERDAM NEwS, Dec. 8, 1990, at 5 (recounting generally negative assessment by black street vendors of ordinances allowing confiscation of illegal vendors' goods); Terence Samuel, Merchant's Fight with Vendor Stirs Germantown Protest, PHILA. INQUIRER, Aug. 20, 1992, at B1 (concerning protest stemming from dispute between Korean merchant and black street vendor who had located in front of merchant's empty store).

28. Karen Carrillo, 125th Street Vendors Tell City They Won't Move to Other Site, N.Y. AMSTERDAM NEwS, July 24, 1993, at 4, 32 (reporting that one black vendor believes non-African storeowners make profits while black street vendors get the crumbs, but storeowners “"don't even want [vendors] to get the crumbs"'); Debbie Officer, Brooklyn Vendors Protest City Anti-Vending Laws as Unfair, N.Y. AMSTERDAM NEws, July 3, 1993, at 3, 38 (quoting vendor who, in reaction to new anti-vending laws, stated: "They're telling me that the little crumbs on the streets, we can't even get from our own people.").

29. See Karen Carrillo, Battle Between Street Vendors, Store Owners on 125 Is Old Feud, N.X. AMSTERDAM NEwS, Dec. 28, 1991, at 7 (dating feud between vendors and merchants in Harlem back to boycotts of white merchants occurring more than 40 years ago).

30. Anthropologist Yvonne Jones assessed the competitiveness of street vendors in "Riverview," a black enclave in a river-port city of the Upper South. Yvonne V. Jones, Street Peddlers as Entrepreneurs: Economic Adaptation to an Urban Area, 17 URB. ANTHROPOLOGY 143 (1988). Professor Jones concluded that the vendors' ability to move into fixed-location businesses was impaired by their structural isolation "from professional and service-related firms which ... provide a variety of managerial and financial assistance to business enterprises. Thus accountants, tax specialists, bankers, and insurance agents were absent from the marketing arena of Riverview street peddlers." Id. at 167. Moreover, the vendors lacked 
the challenge of setting up at a fixed location. As one vendor put it, opening a store that fails may leave one in substantial debt and unable to start over again, whereas if one fails on the street, one "can get more money together in a few months and try again."31

If business success is defined in terms of survival, growth in income, and movement into the formal economy, obtaining a fixed location is not the only measure of success. The experiences of other ethnic groups indicate a number of other directions in which black street vending might develop. ${ }^{32}$ Vendors may move into a fixed site, expand their number of vending locations, or move up the chain of distribution into wholesaling or production. The vendors might ultimately find a market or audience for specialized ethnic goods among customers who do not reside in black enclaves and who are not black, or they may produce or distribute nonethnic goods on a larger scale.

It is important to know both who presently manufactures the merchandise being sold on the streets and who distributes it. Of course, such information is not readily available. Some black vendors have branched out from places like New York City to sell their wares in smaller cities or have gone into importing and distributing goods made in Africa. ${ }^{33}$ Some black publishers and black book distributors started out vending or are strongly supported by vendors' sales. ${ }^{34}$ If black commerce is to be encouraged and the black public sphere developed, it matters whether the products are manufactured in black America, the Caribbean, or Africa or elsewhere. It matters because vending might make a more substantial contribution to the black public sphere by creating jobs beyond the confines of the streets.

Of course, most vendors are not worried about expanding; they are worried about simply staying in business. Staying in business as an illegal black street vendor depends on factors other than general economic conditions. Street merchants must be adept at avoiding or warding off regulators, particularly the police. As blacks, social outsiders to the black mainstream, thorns in the sides

financial assets and conducted their business on a cash, rather than a credit, basis. See also Timothy Bates, Small Business Viability in the Urban Ghetto, 29 J. REGIONAL SCI. 625 (1989).

31. Harlem Vendors vs. Black Establishment, N.Y. AMSTERDAM NEWS, Aug. 14, 1993, at 32.

32. Roger Waldinger et al., Opportunities, Group Characteristics, and Strategies, in ETHNIC ENTREPRENEURS: IMMIGRANT BUSINESS IN INDUSTRIAL SOCIETIES 13, 47 (Roger Waldinger et al. eds., 1990) [hereinafter ETHNIC ENTREPRENEURS]; Roger Waldinger \& Howard Aldrich, Trends in Ethnic Business in the United States, in ETHNIC ENTREPRENEURS, supra, at 49, 71-72; Roger Waldinger et al., Spatial Dimensions of Opportunity Structures, in ETHNIC ENTREPRENEURS, supra, at 106, 124-29.

33. See Jingles, supra note 22, at 3 (quoting Malian vendor who says he sometimes sells in the Bronx and in Philadelphia but prefers Harlem); Deborah Sontag, supra note 22, at B3 (African vendors travel in vans to flea markets across the country; they describe their travels as "going into the bush").

Anthropologist Paul Stoller has studied New York street vendors from Niger. Stoller knows of one vendor who has travelled to 25 states, selling art and goods from Niger. Another vendor has gone into the import/export business. He imports leather goods from Niger that appear to be made for the North American market since they have color combinations that are not typical for Niger. Telephone Interview with Paul Stoller, Anthropologist at West Chester University (Jan. 12, 1994).

34. See Connie Goddard, Aiming for the Mainstream, PUBLISHERS WKLY., Jan. 20, 1992, at 28, 30 (describing informal distribution channels used by small black publishers). 
of small business owners, and economic miscreants in the eyes of the society at large, black street vendors are the targets of discriminatory enforcement and harassment. ${ }^{35}$ The costs of being charged and convicted of violating vending ordinances can be quite steep. For example, in New York, a person found vending without a license will lose her or his wares as well as face substantial fines and court fees. In vending, as in many other public activities, blacks are more vulnerable than others to being stopped by the police. Because laws regulating or prohibiting street vending are selectively enforced in the field, and allow for significant prosecutorial discretion, blacks must be alert to prevent discrimination against black street vendors.

Vendors across the country have found that it makes sense to organize to deal with the police and municipal authorities. ${ }^{36}$ Vending associations have represented vendors' interests in fights over regulation and policing, but they can do more than that. Law and public policy cannot create a commercial culture or a set of business practices, let alone business concerns and institutions, that will allow blacks to achieve the proper balance between competition and cooperation. ${ }^{37}$ Black people must do that for themselves. Vendors' associations would advance the cause if they chose to engage in a

35. See, e.g., J. Zamgba Browne, Street Vendors Face Daily Harassment by Police and Owners, N.Y. AMSTERDAM NEwS, Sept. 25, 1993, at 10 (reporting that Guyanese female vendor, allegedly beaten by police, received support of African International Merchant Agency); Phyllis-Lynne Burns, Showdown at Eastern Market, MiCH. CHRON., June 20-26, 1990, at 3-A (wondering whether 85-year-old vendor, in business for 52 years, was ordered to close before noon because he had expanded into wholesaling or because someone wanted his stand); Ron Dungee, Muslim Prosecuted Under an "Unconstitutional" Law, L.A. SENTINEL, Feb. 1, 1990, at A3 (discussing case of Muslim who was charged with vending without license; the defendant maintained that he exchanged bean pies and newspapers for donations to Nation of Islam); William Hyman, Street Peddlers: Victims of City, Police, Courts, N.Y. AMSTERDAM NEws, Dec. 29,1990 , at 13 (criticizing the vendor regulatory process for number of failings regarding court procedures and confiscation of wares).

The case of Elijah Karriem is also instructive. The Court of Appeals of the District of Columbia upheld the seizure of Karriem's vending license because he failed to keep records and receipts of sales for tax purposes. Karriem v. Gray, 623 A.2d 112 (D.C. 1993). In awarding the city summary judgment, the lower court had refused to consider a memorandum filed by Karriem pro se, in which he had maintained that the proceedings were part of a pattern of harassment directed at him because he is black and because a police officer wanted his girlfriend to have Karriem's vending location. Id. at 113-14 \& $113 \mathrm{n} .2$. The decision of the trial court was affirmed on appeal. Karriem may be the target of excessive scrutiny because he has been a successful litigant in numerous reported cases, including one against the police. See Karriem v. Barry, 743 F.2d 30 (D.C. Cir. 1984) (remanding the case to determine whether Karriem had to execute standard volunteer services agreement containing language objectionable to Karriem in order for him to conduct services for inmates at the prison at Lorton); Lewis v. Green, 629 F. Supp. 546 (D.D.C. 1986) (Karriem was nominal party in a suit brought by Lorton inmate objecting to settlement of class action); Karriem v. Oliver T. Carr Co., 38 Fair Empl. Prac. Cas. (BNA) 882 (D.D.C. 1985) (finding that Karriem was the victim of discriminatory firing); but see Karriem v. District of Columbia, 641 F. Supp. 394 (D.D.C. 1986) (awarding summary judgment to chief of police in an action charging that police unlawfully arrested and assaulted Karriem).

36. See Robert J. Lopez, Pushcan Power, L.A. TIMEs, CrTY TIMES, July 25, 1993, Magazine, at 14 (describing efforts of Hispanic vendors to obtain passage of ordinance allowing street vending); Lester Hinds, Flatbush Street Vendors Organize for Rights Meet, N.Y. AMSTERDAM NEws, Sept. 4, 1993, at 10 (reporting that vendors "form an organization to fight for their rights and demand the setting up of flea markets").

37. Roger Waldinger et al., Conclusions and Policy Implications, in ETHNIC ENTREPRENEURS, supra note 32 , at $177,192-95$. 
measure of self-regulation. For example, Harlem's 125th Street Vendors Association has admitted that the vending operations on the street need regulating. ${ }^{38}$ The members of the Association agreed that a certain number of vendors should move from 125th Street to designated areas on the intersecting avenues. The Association even proposed that vendors be required to pay a weekly tax. Vendor associations could also develop operating rules or codes of conduct which could increase black consumers' confidence. In addition to acting as a sort of trade association or chamber of commerce, vendor associations might use their solidarity for economic purposes, such as bulk purchasing. ${ }^{39}$ Vending associations are well situated to link black grassroots politics with black secular cooperative economics. Such a uniting of grassroots politics and economics, a rare combination in the post-Civil Rights era, is crucial to the development of the black public sphere.

$$
* * * * * * *
$$

Black street vendors by and large could use the benefits and protection accorded legal businesses, though they and their customers may not be able to afford the costs of legality. Expanding the extent of legal vending would strengthen the hand of black vendors fighting police harassment. With a measure of security, they might be able to pursue opportunities to expand or to invest time and resources in professional development. Black vendors should be supported in such endeavors. ${ }^{40}$

Indeed, if the goal is to develop audiences and markets for the output of black productivity and creativity, there ought to be broad support for black street vending. As blacks in America, we must not fall into the trap of automatically equating legitimacy with legality. Just because an enterprise is small, informal, and illegal does not mean that it is not valuable or that it should be disparaged. In fact, all sorts of legal, formal small black business activity are viewed as deviant by the dominant society and unfortunately by blacks as well. ${ }^{41}$ The failure of so very many black businesses due to obstacles beyond blacks' control has given rise to "antibusiness" attitudes and sentiments that steer members of the black middle and working classes away from becoming entrepreneurs and cause blacks to disparage those who, despite

38. Floyd Johnson, 125th St. Vendors Respond to Commissioner Ford, N.Y. AMSTERDAM NEws, Aug. 14, 1993 , at 4.

39. Liz Spayd, On D.C. Streets, Vendors in Struggle, WASH. PoST, Oct. 29, 1991, at A1, A6 (reporting that in an effort to avoid the impact of Korean control of wholesaling, black vendors proposed to travel to New York City to buy directly from importers).

40. The proposals of the Dinkins Administration for providing business services to vendors suggest the correct approach. The City of New York offered to assist legal vendors "by creating off-street sites where appropriate and by offering adult education, English as a second language, small business management, capital access and immigration services." New Street Vendor Program to Protect Small Businesses and Weed Out Illegal Street Vendors, N.Y. VorCE, Apr. 21, 1993, at 1.

41. See Austin, supra note 2. 
the negative attitudes, go into business for themselves. The negative attitudes are produced and reinforced by a scheme of legal regulation that denies the legitimacy of black entrepreneurship such as is exhibited by black street vendors. The imperative of developing the black public sphere means that blacks have to get beyond their doubts about the value of commercial activity, award legitimacy where there is now illegality, and work to bring the law into line.

If blacks are to build viable business concerns, and a business culture and set of ethical operating procedures to go along with them, we will need to appreciate the significance of even the seemingly most paltry forms of retailing. Black businesses need greater acceptance from customers, lenders, potential trading partners, and government authorities. Commercial transactions between blacks must be made less exploitative so that racial solidarity and trust can be built around commercial enterprises. If black consumers come to expect fair prices and fair treatment from black merchants of all sorts, they will have an actual stake in black businesses and come to realize that they do. The lesson of economic advancement through economic cooperation must be taught with words and deeds, and delivered at every level and at every opportunity. There is no better place for the instruction to begin than in the streets. Street vending is a microcosm of black entrepreneurship, with all of its potential and its problems. Street vending is open, obvious, and notorious economic lawbreaking. And finally, street vending presents an opportunity and a site where ordinary, everyday black people, whether sellers or consumers, can engage in the political struggle to build a more viable black public sphere and actually experience firsthand the results of their labor. 
$$
\text { . }
$$ 